\title{
Evaluation of 'Ceres Tonic' plantain (Plantago lanceolata) as a lactation feed for twin-bearing ewes
}

\author{
H.G. JUDSON ${ }^{1}$, R. McANULTY ${ }^{2}$ and R. SEDCOLE ${ }^{2}$ \\ ${ }^{1}$ Agricom, P.O Box 3761, Christchurch \\ ${ }^{2}$ Lincoln University, P.O Box 84, Lincoln University \\ gjudson@agricom.co.nz
}

\begin{abstract}
A field experiment evaluated the effect of plantain (Plantago lanceolata) on ewe and lamb liveweight changes and ewe faecal egg count (FEC) during lactation. Pregnant ewes were randomly allocated to either plantain or perennial ryegrass (Lolium perenne) pastures. Ewes remained on the treatments from one week before lambing until weaning. In Year 1, stocking rate in each treatment group was adjusted weekly to maintain a constant pasture cover. In Year 2, all ewes were set-stocked at $10 /$ ha. All ewes were dosed with Teladorsadagia circumcincta larvae 7 days before parturition. FEC and liveweight of ewes and lambs were monitored weekly. In both years, lamb liveweight gain was faster on plantain than on perennial ryegrass. During lactation, ewe liveweight on ryegrass decreased while increasing on plantain. Ewe peri-parturient FEC for the plantain treatment group was significantly lower than ewes grazing perennial ryegrass $(\mathrm{P}=0.03)$. Despite both treatments growing similar amounts of forage, the carrying capacity (ewes/ha) on plantain was lower suggesting animal production differences were a result of differences in daily intake whether grazing at a common pasture cover or while grazing at the same stocking rate.
\end{abstract}

Keywords: lactating ewe, lamb, lactation, carrying capacity, internal parasites

\section{Introduction}

Achieving lamb weaning liveweights at 12 weeks of age that are heavy enough for slaughter $(36-40 \mathrm{~kg})$ offers financial advantages to producers through premiums for chilled trade, lower total feed consumption, elimination of the weaning check and a probable reduction in anthelmintic use.

In the first 6 weeks after birth, lamb growth is largely determined by daily milk intake and as a consequence, milk production of the ewe. Milk production is not only affected by factors such as ewe genotype and the number of lambs suckling, but also the nutritional status of the ewe during pregnancy and lactation. Over the ewes lactation lambs continue to suckle but with time more of the daily energy intake of lambs comes from forage, especially for twins. Therefore, the daily allowance and quality of forage during lactation are important factors promoting lamb growth.

Initial investigations of the value of plantain as a forage plant identified the possibility of anthelmintic properties (Rumball et al. 1997) but poor lamb growth on the plantain cultivar 'Grasslands Lancelot' was reported (Fraser \& Rowarth 1996). However, recent experiments have shown promising results where reproductive growth is minimised through cultivar choice and grazing management (Moorhead et al. 2002). Preliminary studies of lactating ewes grazing plantain indicated potential benefits to lamb growth rate compared with ryegrass (Judson 2008). Improvements in lambs growth from grazing plantain may be due to increased metabolisable protein supply (Fulkerson et al. 2008), and greater dry matter intake as a consequence of a rapid fractional degradation rate (Burke et al. 2000). A sward structure which promotes easy harvesting, improved resilience to internal parasites, and/or through increased dry matter allowances as a consequence of early spring production may also affect lamb growth rates (A.J.E. Moorhead pers. comm.).

The aim of this experiment was to evaluate plantain as a lactation forage to improve lamb growth rates and ewe condition and to reduce faecal egg output.

\section{Methods}

Over 2 years, a replicated field experiment was carried out at Ceres Research Centre, Canterbury, New Zealand. Pregnant ewes balanced for scanning percentage in Year $1(n=75)$ or twin bearing ewes in Year $2(n=60)$ were randomly allocated to one of two forage treatment groups (replicated 3 times) being either plantain ( $c v$. 'Tonic') or perennial ryegrass (Lolium perenne) ( $c v$. 'Commando', infected with AR1 endophyte). Clover (Trifolium repens) was chemically eliminated from both pastures during Year 1. Ewes remained on the treatments from one week before lambing (early August) through lactation until weaning in November which corresponded to 95 and 87 days after mean lambing date for Year 1 and 2, respectively.

In Year 1, stocking rates in each treatment group were adjusted weekly by increasing or decreasing the grazing area to maintain pasture cover between 1000 
Table 1 Pasture covers, growth rates, stocking rates and lamb and ewe liveweight changes from Year 1, when stocking rates were adjusted to achieve constant pasture cover.

\begin{tabular}{|c|c|c|c|}
\hline & Perennial ryegrass & Plantain & Sig. \\
\hline Average pasture mass (kg DM/ha) & 1100 & 950 & NS \\
\hline Pasture growth (kg DM/ha/d) & 71 & 72 & NS \\
\hline Stocking rate (ewes/ha) & 15.1 & 10.4 & * \\
\hline Weaning (\%) & 152 & 143 & NS \\
\hline Lamb LWG (g/d) & 296 & 376 & * \\
\hline Weaning wt (kg) & 33.9 & 41.1 & * \\
\hline$\%$ reaching $36 \mathrm{~kg}$ liveweight & 39 & 85 & * \\
\hline Total weaning wt (kg/ha) & 785 & 618 & * \\
\hline Ewe liveweight change (kg/ewe) & -7.5 & 6.6 & * \\
\hline
\end{tabular}

NS $=$ not significant, ${ }^{*}=\mathrm{P}<0.05$

Table 2 Pasture covers, growth rates, stocking rates and lamb and ewe liveweight changes from Year 2 when animals were setstocked.

\begin{tabular}{|c|c|c|c|}
\hline & Perennial ryegrass & Plantain & Sig. \\
\hline Average pasture mass (kg DM/ha) & 2100 & 600 & * \\
\hline Pasture growth (kg DM/ha/d) & 67 & 69 & NS \\
\hline Stocking rate (ewes/ha) & 9.5 & 10.1 & NS \\
\hline Weaning (\%) & 197 & 187 & NS \\
\hline Lamb LWG (g/d) & 309 & 346 & * \\
\hline Weaning wt (kg) & 30.7 & 33.9 & * \\
\hline$\%$ reaching $36 \mathrm{~kg}$ & 7 & 29 & * \\
\hline Total weaning wt (kg/ha) & 574 & 635 & * \\
\hline Ewe liveweight change (kg) & -2.3 & 7.2 & * \\
\hline
\end{tabular}

NS $=$ not significant, ${ }^{*}=\mathrm{P}<0.05$

Table $3 \quad$ Mean FEC before and after lambing of ewes grazing ryegrass or plantain swards in Year 1 and Year 2.

\begin{tabular}{lccccccccccccc}
\hline & & \multicolumn{10}{c}{ Time (weeks relative to parturition) } \\
Treatment & Year & -4 & -3 & -2 & -1 & 3 & 4 & 5 & 6 & 7 & 8 & 9 & 11 \\
\hline Plantain & 1 & 56 & 120 & 105 & 31 & 65 & 115 & 150 & 61 & 66 & 85 & 76 & 30 \\
Ryegrass & 1 & 42 & 71 & 45 & 46 & 129 & 239 & 201 & 130 & 179 & 142 & 101 & 131 \\
Plantain & 2 & & 65 & & & 446 & 642 & 276 & 294 & 146 & 160 & 141 \\
Ryegrass & 2 & & 34 & & & 333 & 696 & 890 & 1143 & 1677 & 485 & 433 \\
\hline
\end{tabular}

and $1200 \mathrm{~kg} \mathrm{DM} / \mathrm{ha}$ and thus allow ewes and lambs to potentially achieve maximum intake. This resulted in an average stocking rate of 15.1 and 10.4 ewes/ha for the ryegrass and plantain treatments, respectively.
In Year 2, ewes were set-stocked at $10 /$ ha. All ewes were dosed with 10,000 (Year 1) or 30,000 (Year 2) Teladorsadagia circumcincta larvae 7 days before parturition. Liveweight changes of ewes and lambs 
were monitored weekly. Faecal egg count (FEC) were determined weekly by taking faecal samples from all ewes from up to 4 weeks before parturition until weaning and weekly in all lambs from 8 weeks after birth until weaning. Results from lamb FEC will be discussed elsewhere.

FEC were determined using a modification of the McMaster method (MAFF 1979).

Pasture mass was estimated weekly by cutting to ground level with an "Heiniger" electric shearing handpiece, three quadrats (each measuring $0.25 \mathrm{~m}^{2}$ ) placed randomly in the pasture. A sub-sample of cut herbage was dried at $65^{\circ} \mathrm{C}$ for $24 \mathrm{~h}$ before weighing. When all lambs had been born, each plot was divided in half using a temporary fence and ewes and lambs shifted between the two sides until weaning. Ewes and lambs were shifted every 4 to 10 days depending on pasture cover.

\section{Statistical analysis}

Liveweight data were analysed using REML in Genstat. FEC data were log transformed to (base 10) of counts +1 , mainly on the basis of residual diagnostic plots. The transformed data were analysed using REML in Genstat. The repeated measures nature of the liveweight and FEC data were allowed for by the inclusion of the covariance error term, set to have a uniform correlation of order 1 .

\section{Results}

\section{Year 1}

The average pasture mass on each treatment over lactation was similar. The aim of keeping pasture mass between 1000 and $1200 \mathrm{~kg} \mathrm{DM} / \mathrm{ha}$ was achieved for ryegrass although the plantain treatment fell slightly short of this target (Table 1).

There was no difference in pasture growth rates between ryegrass and plantain treatments. Stocking rate to achieve a similar average pasture mass was lower for plantain treatment group (10.4 ewes/ha) compared with the perennial ryegrass treatments (15.1 ewes/ha). Based on pasture growth rate and stocking rate this corresponded to an apparent daily intake of 4.7 and 6.9 $\mathrm{kg}$ DM/ewe-lamb pair/day for ryegrass and plantain treatments, respectively.

Both lamb liveweight gain (LWG) and weaning weight were higher on plantain treatments. As a consequence, more lambs exceeded $36 \mathrm{~kg}$ at weaning on plantain, although the ryegrass treatment group produced a greater weight of lambs per hectare at weaning. During lactation, ewes on perennial ryegrass lost $7.5 \mathrm{~kg}$ of liveweight while those on plantain increased liveweight by $6.6 \mathrm{~kg}$.

\section{Year 2}

Average pasture mass in Year 2 on ryegrass treatments $(2100 \mathrm{~kg} \mathrm{DM} / \mathrm{ha})$ was much higher than on plantain treatments (600 kg DM/ha) (Table 2). Plantain pasture cover fell from $1200 \mathrm{~kg} \mathrm{DM} /$ ha at introduction to around $550 \mathrm{~kg} \mathrm{DM} / \mathrm{ha}$ in the first 3 weeks and remained at this cover for the remainder of the experiment. The cover on the ryegrass increased steadily to reach $3500 \mathrm{~kg} \mathrm{DM} / \mathrm{ha}$ at the completion of the experiment. Based on pasture growth rate, stocking rate and changes in pasture cover this corresponded to an apparent daily intake of 3.2 and $6.8 \mathrm{~kg} \mathrm{DM} /$ ewe-lamb pair/day for ryegrass and plantain treatment groups, respectively.

There was no difference in pasture growth rates between ryegrass and plantain treatment groups. Despite similar pasture growth rates, average pasture mass remained constant for plantain but continued to increase for perennial ryegrass. Both lamb growth rate and weaning weight were higher on plantain compared to perennial ryegrass. As a consequence, more lambs on plantain exceeded $36 \mathrm{~kg}$ at weaning contributing to a greater weight of lambs per hectare at weaning than on ryegrass. During lactation, ewes on perennial ryegrass lost $2.3 \mathrm{~kg}$ of liveweight while those on plantain increased liveweight by $7.2 \mathrm{~kg}$.

FEC of ewes grazing ryegrass or plantain swards were not significantly different before lambing (Table 3). However, the rise in FEC before lambing was greater and lasted longer for ewes on ryegrass than for those of plantain. There were significant effects of time ( $\mathrm{P}$ $<0.001)$, treatment $(\mathrm{P}<0.001)$ and year $(\mathrm{P}<0.001)$ on ewe FEC with a significant interaction between time and year $(\mathrm{P}<0.001)$. This interaction showed that ewe FEC's were higher in Year 2 from 3 weeks after lambing. This was probably a reflection of the increased larval challenge given to ewes in Year 2. The time effect reflects the normal (Brunsdon \& Vlassoff 1971) post-lambing rise in FEC in ewes grazing pasture during lactation (Table 3). After lambing, the plantain treatment resulted in a $48 \%$ reduction $(\mathrm{P}<0.001)$ in ewe FEC compared to ryegrass. Final egg counts for ewes on ryegrass were three to four times higher than those on plantain.

\section{Discussion}

The results of this experiment suggest there are considerable benefits to lambs production systems of grazing plantain before weaning. Regardless of whether or not this comparison was carried out on an equal cover or equal stocking rate basis, both lambs and ewes gained more liveweight on plantain than on perennial ryegrass.

Where stocking rates were adjusted to achieve an equal cover (Year 1), large differences in both ewe and lamb liveweight changes were observed. Differences in 
liveweight of lambs at weaning were such that more lambs on plantain achieved a slaughter weight of $36 \mathrm{~kg}$ compared with those on ryegrass. However, because plantain was stocked at a lower rate than ryegrass the total weight of lambs weaned was lower. This simple comparison of total weaning weight does not reflect the opportunity to finish more lambs later in the season in systems where lambs grow fast and are sold early.

Plantain required approximately $30 \%$ less stock over lactation to maintain the desired pasture cover compared to ryegrass, despite pasture growth rates being similar. This suggests the carrying capacity of plantain over this period is lower than ryegrass not because of poorer rates of dry matter production, but because of increased intake per animal as indicated by the crude estimates of intake calculated.

In Year 2, where stocking rates were equal (10 ewes/ ha) lambs on plantain treatments were heavier at weaning but differences between treatments were smaller than in Year 1. Weaning weights of lambs on the plantain treatments were lower in Year 2 compared to Year 1. A lower weaning weight in Year 2 is likely to be a result of an 8 day earlier weaning age and a reduced daily intake as a result of an increase in stocking rate through a higher weaning percentage. Although the stocking rate of ewes on the plantain treatment was similar between years (10 ewes/ha), the increased weaning percentage between Year 1 and Year 2 (143 versus $187 \%$ ) meant there was 4 extra lambs per hectare in the plantain treatments in Year 2 compared to Year 1.

In Year 2 under a common stocking rate pasture cover on plantain treatments was around $600 \mathrm{~kg} \mathrm{DM} /$ ha for much of lactation but ryegrass cover increased throughout. As in Year 1, pasture growth rates were not different between treatments suggesting again that the carrying capacity of plantain was lower due to the higher daily intake of ewes and lambs on this treatment. Lamb growth rates on ryegrass treatments were similar between Year 1 (296 g/day) and Year 2 (309 g/day) despite the increased pasture cover in Year 2. This observation suggests the higher stocking rate in Year 1 was not responsible for the differences between treatments in that year. Liveweight gain of lambs from the plantain treatments decreased from 375 $\mathrm{g} /$ day in Year 1 to $346 \mathrm{~g}$ /day in Year 2, could be due to lower average grazing cover restricting intake in Year 2 although the crude estimates of intake do not support this interpretation. The benefits of using plantain during lactation appear to be intake-related and therefore rely on ewes and lambs getting the opportunity to eat more.

Regardless of pasture cover, ewes on plantain increased liveweight over lactation whereas their counterparts on ryegrass lost liveweight. Increased liveweight on the plantain treatment is consistent with the suggested increase in daily intake. In many sheep production systems liveweight gain during lactation could be of value if the environment does not allow for the regaining of liveweight and body condition after weaning or for hoggets or light ewes.

Ewes grazing plantain produced a lower FEC throughout lactation compared to those on ryegrass. This is similar to results with chicory (Athanasiadou et al. 2007) and protein supplementation (McAnulty et al. 2005). The mechanism for this effect with plantain is not clear but the ability of plantain to increased metabolisable protein supply (Fulkerson et al. 2008) may be one possibility.

\section{Conclusion}

Grazing plantain during lactation is likely to be an advantage in systems where lower stocking rates are acceptable and average weaning weight is of more value than total weaned weight per hectare. Plantain grazing systems may also be of benefit where increasing ewe liveweight over lactation (in hogget mating systems, for example) is desirable. Plantain grazing systems would also appear to have some benefits for internal parasite control programmes.

\section{ACKNOWLEDGEMENTS}

The authors thank Marilyn Parris, Brent Macaulay, Christine Lima and Anya Armstrong for technical assistance and Allister Moorhead for agronomic advice.

\section{REFERENCES}

Athanasiadou, S.; Gray, D.; Younie, D.; Tzamaloukas, O.; Jackson, F.; Kyriazakis, I. 2007. The use of chicory for parasite control in organic ewes and their lambs. Parasitology 134: 299-307.

Brunsdon, R.V.; Vlassoff, A. 1971. The post parturient rise: Comparison of the pattern and relative generic composition of strongyle egg output from lactating and non-lactating ewes. New Zealand Veterinary Journal 19: 19-25.

Burke, J.L.; Waghorn, G.C.; Brookes, I.M.; Attwood, G.T. 2000. Formulating total mixed rations from forage - defining digestive kinetics of contrasting species. Proceedings of the New Zealand Society of Animal Production 60: 9-14.

Fulkerson, W.J.; Horadagoda, A.; Neal, S.J.; Barchia, I.; Nandra, S.K. 2008. Nutritive value of forage species grown in the warm temperate climate of Australia for dairy cows: Herbs and grain crops. Livestock Science 114: 75-83.

Fraser, T.J.; Rowarth, J.S. 1996. Legumes, herbs or grass for animal performance? Proceedings of the New Zealand Grassland Association 58: 63-66.

Judson, H.G. 2008. Preliminary evaluation of 
Tonic plantain (Plantago lanceolata) as a feed for ewe lactation. pp. 130-131. In: Proceedings $23^{\text {rd }}$ Grasslands Society of NSW conference, Tamworth, NSW, Australia.

MAFF, 1979. Manual of veterinary parasitological laboratory techniques. Ministry of Agriculture, Fisheries and Food, Agricultural Development and Advisory Service. Technical Bulletin. No 18, H.M.S.O. London.

McAnulty, R.W.; Xie, H.; Stankiewicz, M.; Logan, C.M.; Keeley, M.J.; Jay, N.P.; Gibbs, J.S.; Sykes, A. R. 2005. Four years of studies on protein supplementation of peri-parturient ewes at Lincoln University. p.138. In: Proceedings of 20th International Conference of the World Association for the Advancement of Parasitology (WAAVP).
Moorhead, A.J.E.; Judson, H.G.; Stewart, A.V. 2002. Liveweight gain of lambs grazing "Ceres Tonic" plantain (Plantago lanceolata) or perennial ryegrass (Lolium perenne). Proceedings of the New Zealand Society of Animal Production 62: 171-173.

Rumball.W.; Keogh, R.G.; Lane, G.E.; Miller, J.E.; Claydon, R.B. 1997. 'Grasslands Lancelot plantain' (Plantago lanceolata L.) New Zealand Journal of Agricultural Research 40: 373-377. 